\title{
HIGH-RESOLUTION GEOMORPHOLOGICAL MAPPING OF THE SHALLOW CONTINENTAL SHELF WEST OF THE KAVALA BAY, NORTH AEGEAN
}

\author{
Panagiotopoulos I.P. ${ }^{1}$, Kapsimalis V. ${ }^{1}$, Ioakim Chr. ${ }^{2}$, Karageorgis A. ${ }^{1}$, \\ Rousakis G. ${ }^{1}$, Morfis I. ${ }^{1}$, Hatiris G.A. ${ }^{1}$, Anagnostou C. ${ }^{1}$, Koukoulis A. ${ }^{2}$, \\ Papatrechas Ch. ${ }^{2}$, Koutsovitis P.D. ${ }^{2}$, Economou G. ${ }^{2}$, Tsapara E. ${ }^{2}$ and \\ Kyriakidou C. ${ }^{1}$
}

${ }^{1}$ Hellenic Center for Marine Research, Institute of Oceanography, 46.7 km Athens-Sounio Ave., 19013 Anavyssos, Greece, jpanagiot@hcmr.gr,kapsim@hcmr.gr,ak@hcmr.gr, rousakis@hcmr.gr,gianmor@hcmr.gr,gahatiris@hcmr.gr,chanag@hcmr.gr,hkyriakid@hcmr.gr

${ }^{2}$ Institute of Geology and Mineral Exploration, ${ }^{\text {st }}$ Spirou Louis St., Olympic Village, 13677

Acharnae,Greece,ioakim@igme.gr,johncats11@igme.gr,papatrechas@windowslive.com, petroskoutsovitis@yahoo.com,dop@igme.gr,efi.tsapara@igme.gr

\begin{abstract}
Prominent geomorphological features of the shallow continental shelf west of the Kavala Bay (Loutra Eleftheron-Nea Peramos) were mapped using the data from a hydrographic survey (June 2014) of 320 nautical miles during which high-resolution multibeam bathymetry and seismic-reflection subbottom profiling were carried out simultaneously. A fault zone comprised by a set of two primary sigmoidal gravity faults (recorded lengths and measured offsets: $12 \mathrm{~km}, 5 \mathrm{~km}$ and $>40 \mathrm{~m}, 25 \mathrm{~m}$, respectively), with distinct expression on the seabed, and three other secondary gravity faults situated southern of the major faults, revealing synsedimentary tectonics, was identified. The striking difference between the texture of the footwall block sediments of the northern major fault and the texture of the sediments occupying the deep hanging wall block of the southern major fault emphasizes the impact of local tectonics on the sedimentary evolution of the study area. Concerning the observed bedforms, the most interesting were the sand dunes occurring at depths from $25 \mathrm{~m}$ to $65 \mathrm{~m}$ at least and occupying the northeast part of the study area. Their large dimensions and orientation in relation to the coastline position imply as a mechanism for their formation intense bottom-current activity.
\end{abstract}

Keywords: gravity faults, submarine dunes, sand deposits.

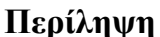

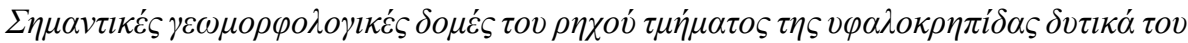

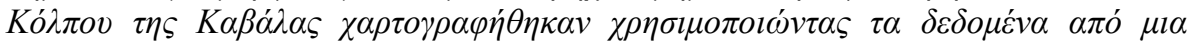

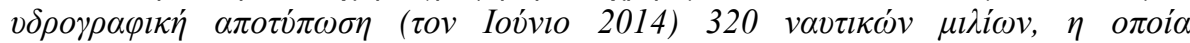



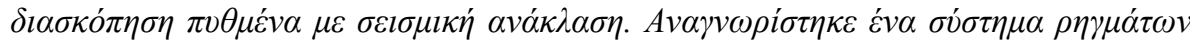

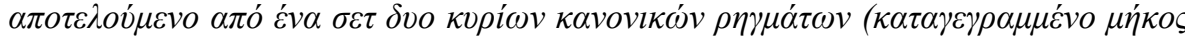



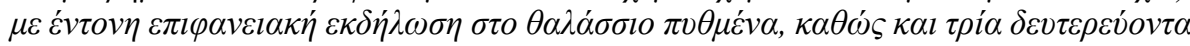




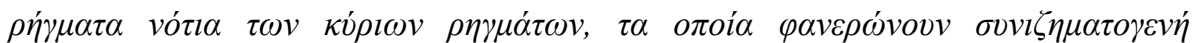

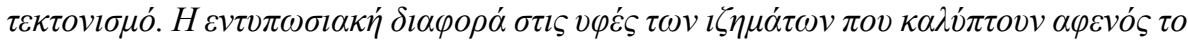

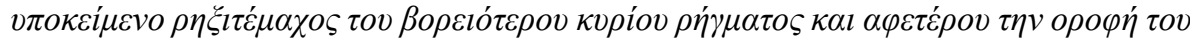

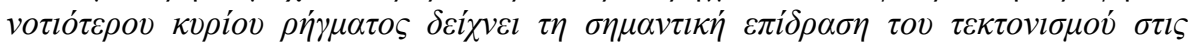

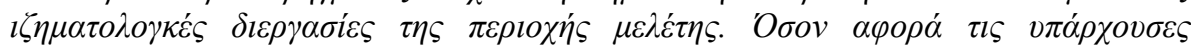

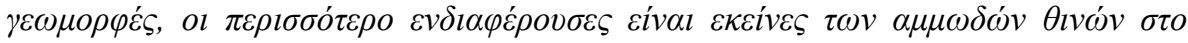

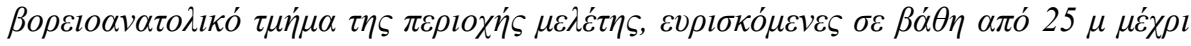

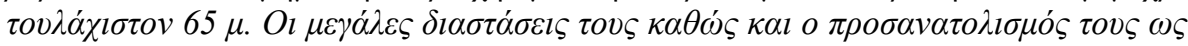

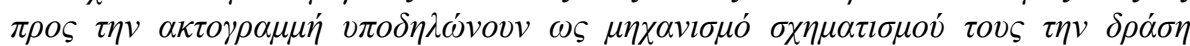



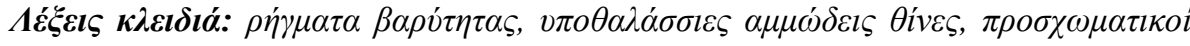
$\dot{\alpha} \mu \mu о \imath$.

\section{Introduction}

The spatial distribution patterns of grain size fractions, minerals and chemical elements in surface sediments as well as the main geomorphological features and the post Last Glacial Maximum (LGM) evolution of the North Aegean continental shelf have been studied by Perissoratis et al. (1987), Perissoratis and Van Andel (1988), Perissoratis et al. (1988), Perissoratis and Mitropoulos (1989) and Perissoratis and Ioakim (2010) through the interpretation of single-beam bathymetry, seismic subbottom profiling and sedimentological analyses. However, recent technology developments have triggered renewed research into continental shelves. A new generation of high-resolution swath mapping sonar systems and Chirp subbottom profilers have enabled geomorphological analysis of the seabed and upper layers of bottom substrate in great detail and coverage, far surpassing the capabilities of earlier generation instrumentation. Small- and large-sized bedforms, such as ripples, ribbons, scars and dunes, high-resolution stratification of the upper seabed substrate and internal structure of the continental shelves are now more clearly detectable and, therefore, more reliable submarine geomorphological interpretations can be accomplished.

The principal aim of the present study is the high-resolution mapping of the prominent geomorphological characteristics of the shallow continental shelf extending between Loutra Eleftheron and Nea Peramos, west of the Kavala Bay (North Aegean). The internal structure of the uppermost seabed substrate of the study area is briefly described. Furthermore, a secondary purpose that is accomplished is the preliminary analysis of bulk mineralogy and chemistry of the surface sediments of the Loutra Eleftheron-Nea Peramos inner continental shelf.

\section{Physiographic setting}

The study area belongs to the lower tectonic unit of the Rhodope Massif (Pangeon Carbonate Platform) comprising massive marbles, micaceous gneisses, mica schists, calc-silicate schists and amphibolites (Kilias and Mountrakis, 1990). Outcrops of plutonic rocks, usually monzonite, granodiorite and gabbro, are also present within the unit. The geotectonic emplacement of the plutons is considered to be related with the post-collisional collapse of the Hellenic orogeny (Jones et al., 1992; Brun and Sokoutis, 2007). The Kavala-Symvolon pluton is located in the coastal area between Loutra Eleftheron and Kavala. It is an amphibole-biotite granodiorite with minor amounts of diorite, tonalite, monzogranite and monzodiorite. It has a medium- to coarse-grained texture and consists of quartz, plagioclase, K-feldspar, amphibole and biotite, with minor amounts of titanite, allanite, apatite, zircon and epidote (Neiva et al., 1996). In the littoral area of Loutra Eleftheron-Nea Peramos, the differential sorting of sediments derived by the weathering, fragmentation and degradation of this pluton causes the formation of placer deposits ("black sand"), which have high economic value (Pergamalis et al., 2001a, b; Eliopoulos et al., 2014; Papadopoulos et al., 2015). The Rare Earth Elements (REE) bearing minerals of "black sand" are monazite, allanite, titanite, uraninite, zircon and apatite. The granulometric and mineralogical composition of seabed sediments 
in the adjacent continental shelf has been presented by Conispoliatis and Lykousis (1986), Perissoratis et al. (1987), Perissoratis and Van Andel (1988), Perissoratis and Mitropoulos (1989) and Perissoratis and Ioakim (2010).

The outer Kavala Bay was exposed under subaerial conditions at the LGM. Up to 14,000 or perhaps 16,000 yrs BP, the Strymon River was flowing along and very close to the Loutra Eleftheron littoral zone, forming occasionally an ephemeral lake at the outer shelf of the Kavala Bay and, finally, discharging into the Aegean Sea. At that period, an extended dune field had developed in the middle shelf of the Kavala Bay, between Nea Peramos and West Thassos. At 10,500 yrs BP, the sea advanced up to the Nestos channel, forming a tongue-like embayment that protruded into the tectonic basin of the Kavala Bay, while till 7,500 yrs BP the bay was flooded with sea water.

\section{Materials and Methods}

The current study is based on the examination of 320 nautical miles of high-resolution multibeam bathymetry and seismic profiling (Fig. 1) carried out simultaneously by the R/V Alkyon of the Hellenic Centre for Marine Research (HCMR) during June 2014. The survey speed varied from 5 to 7 knots, whilst a total of about $140 \mathrm{~km}^{2}$ of seafloor area was covered.

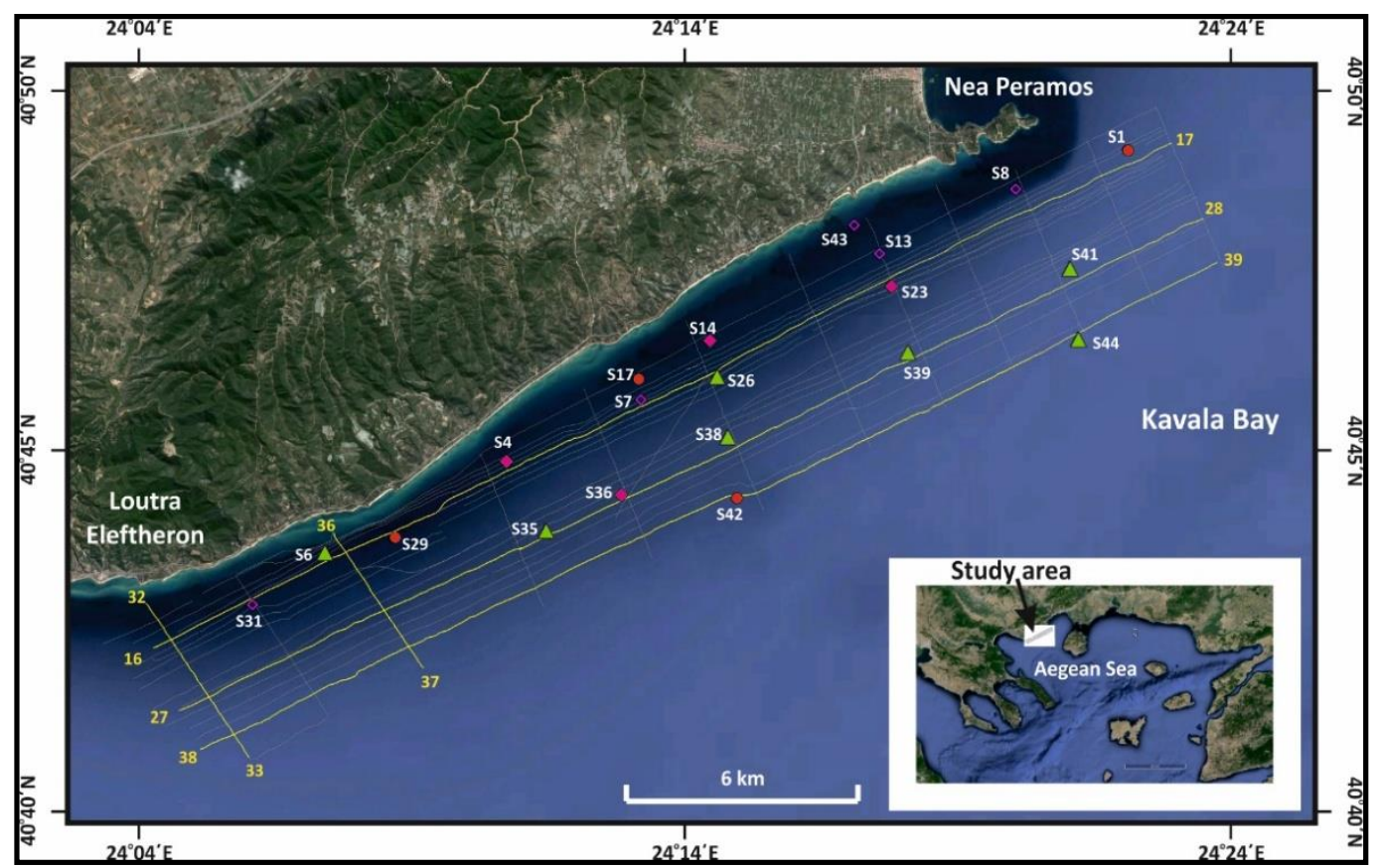

Figure 1 - Location map of the study area illustrating the multibeam bathymetry and seismic-reflection profiling tracks as well as the sediment sampling positions.

The bathymetric survey was performed using a hull-mounted Reson SeaBat 7125 sonar (frequency of operation: 200/400 kHz; applied half-swath angle: 60-64' maximum received beams: 256/512). Several sound velocity profiles, obtained from conductivity-temperature vs depth (CTD) casts at various stations (30-110 $\mathrm{m}$ deep) in the study area, were incorporated into the acquisition software of the multibeam echosounder to calibrate the position and accuracy of recorded depth values. The estimated error in the measured depths was within a few centimeters.

Seismic reflection profiles were acquired with a hull-mounted Chirp subbottom profiler of Geoacoustics (frequency of operation: 2-7 kHz). An average sound velocity of 1,550 m/s was applied for the calculation of the thickness of seabed substrate layers observed in the obtained seismic-reflection profiles. 
An integrated navigation system (Coda Octopus F185+R) was used for the accurate positioning (estimated error less than $2 \mathrm{~cm}$ ) of the recorded acoustic data.

Finally, surface sediment samples recovered from the Loutra Eleftheron-Nea Peramos inner continental shelf (Fig. 1) were analyzed for the determination of their mineralogical composition using X-Ray diffraction (XRD). The X-Ray diffractometer was a Panalytical X'pert-Pro with a $\mathrm{Cu}$


$\mathrm{mA}$ current. The random powder mounts of samples, prepared by back loading, were scanned from $2^{\circ}$ to $70^{\circ} 2 \theta$. Powder diffraction data were collected at room temperature. Data were evaluated with the XPert High-Score (Version 2004) (PANalytical B.V., Almelo, The Netherlands) and the EVA® software (DIFFRACplus EVA v12.0, Bruker AXS GmbH) and managed with the PDF-2 database (International Centre for Diffraction Data, Newtown Square, PA, USA) with detection limit of $1 \%$. Also, samples made into polished thin sections were examined in the SEM laboratory of IGME, (SEM system JEOL JSM-5600 coupled with an EDS system of Oxford Instruments), where the analysis conditions were $30 \mathrm{KeV}$ acceleration voltage, $3 \mathrm{nA}$ beam current, spot diameter of 10-30 $\mu \mathrm{m}$ and detection limit of $0.1 \%$.

\section{Results and Discussion}

\subsection{Sand dunes}

An extended field of sand dunes (divided into a NE and a SW sector) develops in the northeast part of the study area and close to the Kavala Bay (Fig. 2, 3 and 4), at water depths ranging from about $25 \mathrm{~m}$ to $65 \mathrm{~m}$ at least. The longitudinal axis of these dunes usually exceeds $4 \mathrm{~km}$ and is orientated to a NW-SE direction. The average height of the dunes fluctuates between $1.5 \mathrm{~m}$ and $2.5 \mathrm{~m}$, with their maximum height, however, reaching more than $4 \mathrm{~m}$, whilst dune wave length sometimes is even larger than $400 \mathrm{~m}$. The further examination of sand dunes geometry shows that stoss slope usually occurs to NE with its magnitude being less than $2^{\circ}$, whereas leeward side faces to SW displaying slopes higher than $2^{\circ}$. Assuming that the development of these sand dunes is due to coastal bottom currents, then, regarding the aforementioned dune geometry, it may be proposed that the bottom-current activity responsible for the dune formation is remarkably strong and follows a general direction from NE to SW (Fig 4). The large size of the detected sand dunes indicates the action of exceptionally high bottom shear stresses during their formation. Such great shear stresses could be probably initiated when the sea level was in a lower position compared to the present one, for instance during the last marine transgression before the Mid-Holocene (7,500 yrs BP) identified by Perissoratis and Van Andel (1988) and Perissoratis and Mitropoulos (1989). However, it should be noticed that the aforementioned researchers claim that the neighbouring sand field in the inner Kavala Bay is of relict character. This is in contrast with the assumption made for the development of present study's sand dunes.

In general, the mechanisms responsible for the formation, mobility and stability of small- and largescale wavy sand forms have been summarized by Albarracín et al. (2014). The main factors that generate and evolve such bedforms on continental shelves are: (1) the sea level position before or after the post LGM transgression, since it defines the ravinement surface and, consequently, the accumulation space; (2) dominant oceanographic processes, such as tidal currents, littoral currents, storm surges, or sediment transport due to a combination of storms and coastal currents; and (3) the current status of these features, i.e., active, relict or quasi-moribund, implying that wavy sand forms correspond either to reworked transgressive deposits or to post-transgressive active sand waves. An overview of modern shelf sand ridges can be found in Snedden et al. (2011). 


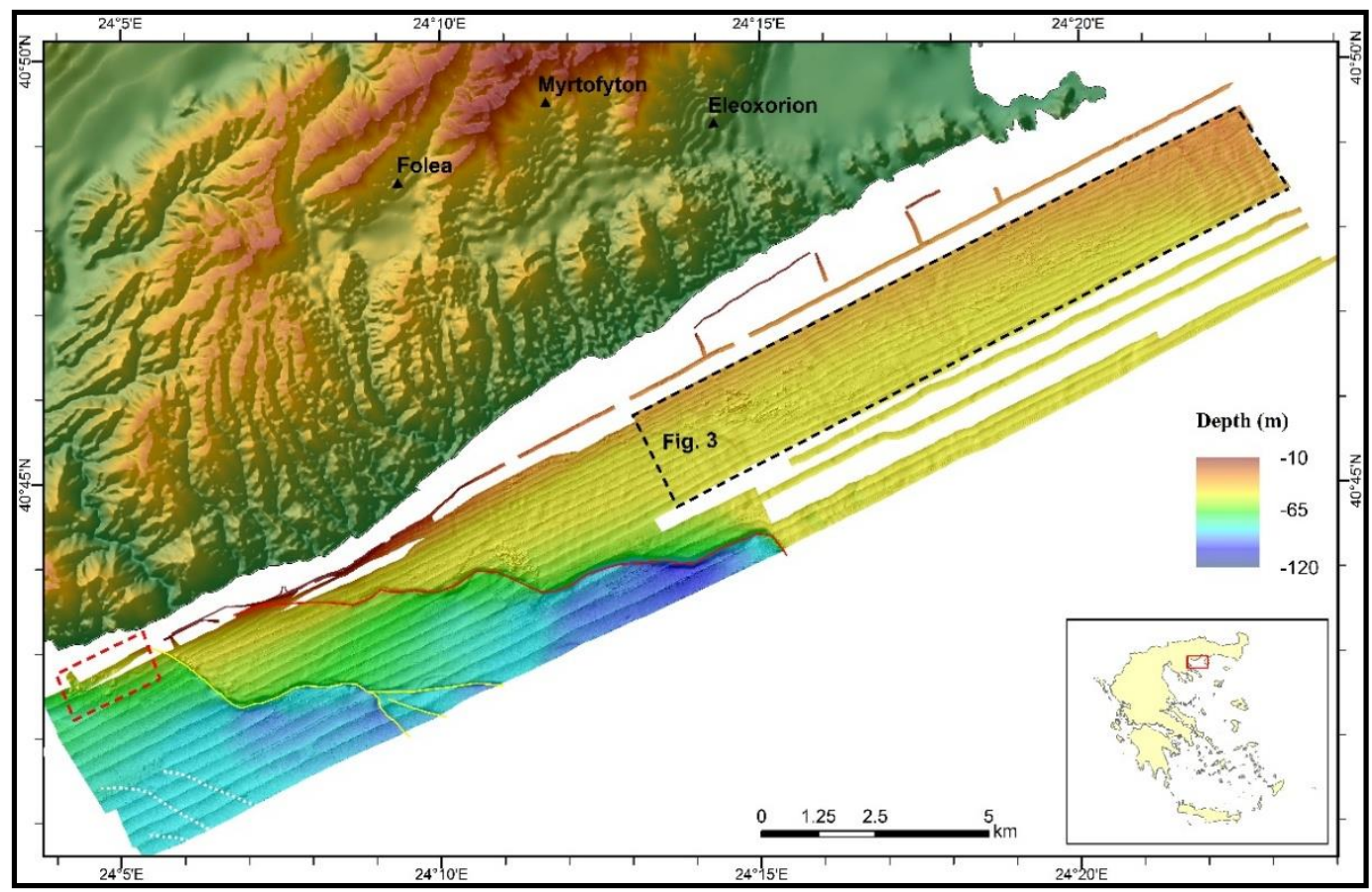

Figure 2 - High-resolution bathymetry map of the study area displaying the main geomorphological features. The black dashed frame encloses the extended field of sand dunes, whereas the red dashed frame encloses rocky outcrops. The northern and southern primary faults are marked by the red and yellow lines, respectively, whilst the dotted white lines indicate the traces of secondary faults. The cell size of the bathymetric grid is $\mathbf{2} \mathbf{m}$ with the coordinate system being UTM35N. The datum of the indicated depths is the local mean sea level.

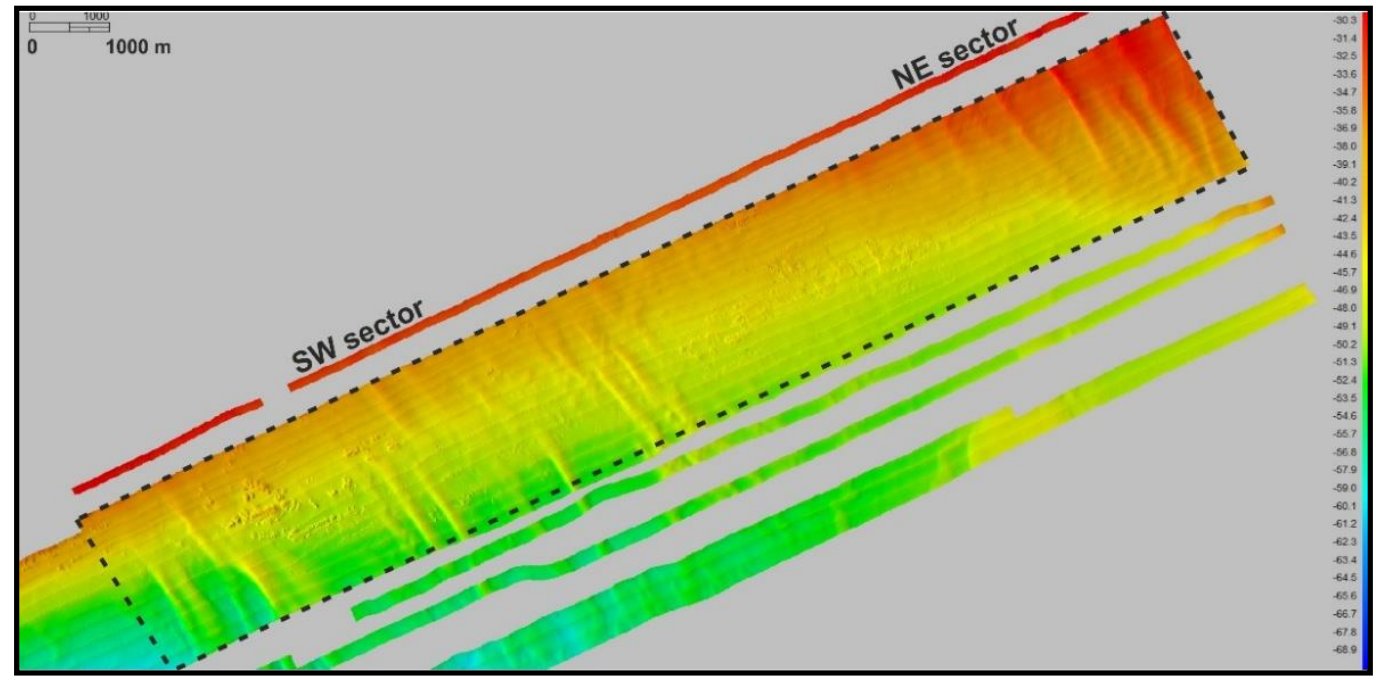

Figure 3 - High-resolution bathymetric image illustrating the shape and arrangement of identified sand dunes. The cell size of the bathymetric grid is $2 \mathbf{~ m}$. 


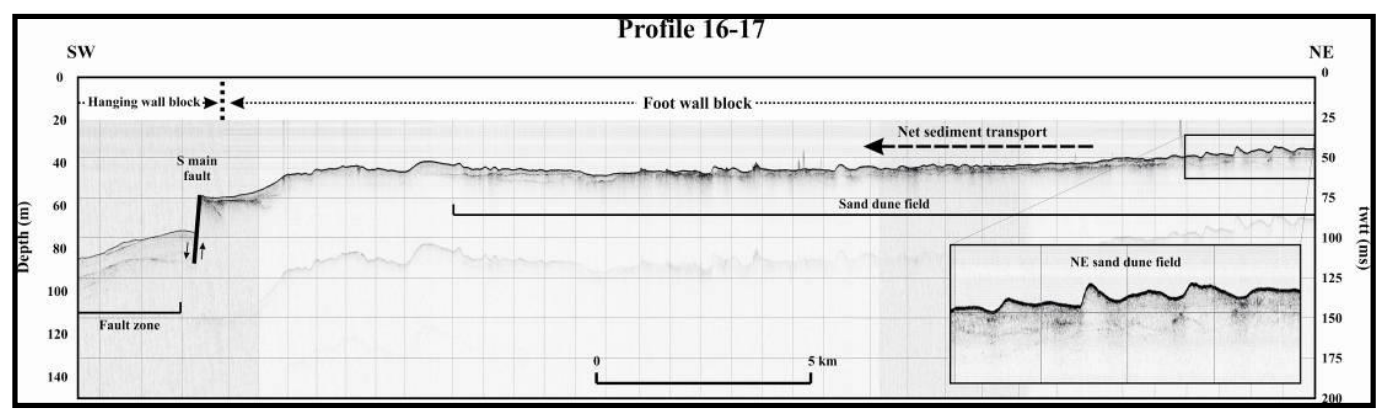

Figure 4 - Seismic-reflection profile displaying the full extent of the sand dune field in the northeast part of the study area. For profile location see Figure 1.

\subsection{Fault zone}

The tectonic feature that dominates the study area is an extensive fault system whose main surface growth follows a sigmoidal shape and develops along the general direction W-E. This system includes a series of normal faults, which demonstrate a contrasting tiered shift and have their hanging walls orientated to a SW direction. The geometry of the fault zone indicates that the entire study area is subjected to an elongation in the horizontal plane caused by the action of tensile stresses.

The identified fault zone comprises two major normal (gravity) faults (northern and southern), detectable at depths down to $95 \mathrm{~m}$ and $110 \mathrm{~m}$, respectively, and three secondary faults located at the southwestern part of the study area (Fig. 2 and 5). The lengths of the recorded ruptures associated with the northern and southern primary fault are $\sim 12 \mathrm{~km}$ and $\sim 5 \mathrm{~km}$, respectively.

In the northern primary fault, the apparent vertical displacement (offset) and horizontal displacement of fault blocks sometimes exceeds $40 \mathrm{~m}$ and $60 \mathrm{~m}$, respectively, while fault plane dips up to $10^{\circ}$ (Fig. 6, see Profile 36-37). The tilting of the hanging wall layers at the contact with the fault plane is indicative of the tensile motions in the fracture zone.

The southern major fault branches off to the east in three divergent segments (see yellow lines in Fig. 2), with the most important segment being the northern one. The maximum measured values concerning the fault offset, horizontal displacement and fault plane dip are $25 \mathrm{~m}, 150 \mathrm{~m}$ and $12^{\circ}$, respectively (Fig. 6, see Profile 36-37).

The secondary faults (Fig. 6, see Profile 32-33) in the southwestern part of the study area reveal synsedimentary tectonics. They are mostly subsurface and do not appear to intersect the upper sedimentary layer. The latter observation implies that these particular faults are not recently active and they should have been formed prior to the deposition of the uppermost sedimentary layer.

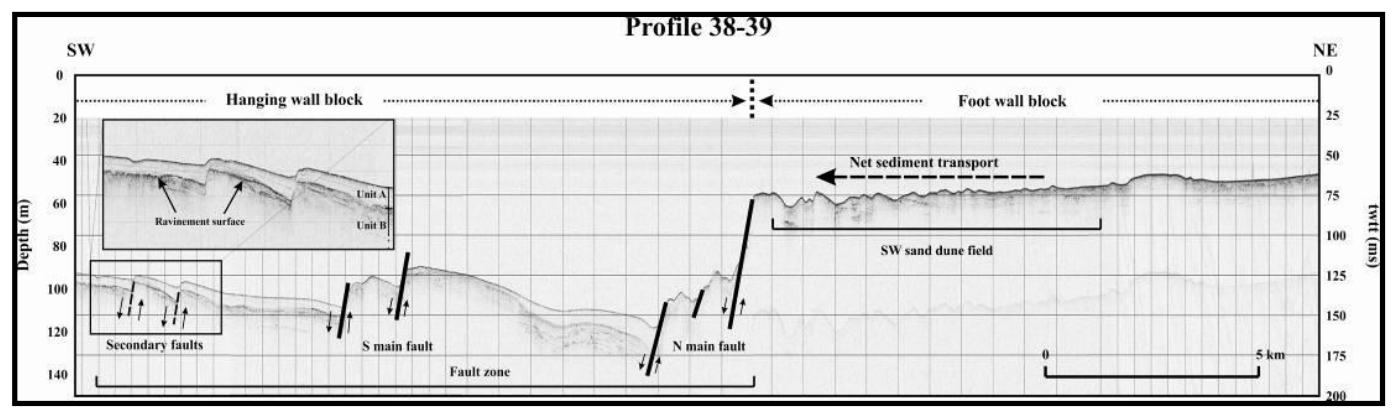

Figure 5 - Seismic-reflection profile demonstrating the fault system in the study area. For profile location see Figure 1. 



Figure 6 - Seismic-reflection profiles focusing on the primary northern and southern fault (left profile) as well as the secondary faults (right profile). For profiles location see Figure 1.

\subsection{Litho-seismic configuration}

The sedimentological processes in the study area are greatly affected by local tectonics since the sedimentology of the shallower footwall block in the northeastern part of the area is considerably different from that of the deep hanging wall block located in the southwestern part of the area.

The sediments of the shallower northeastern footwall block are coarser than those covering the deep southwestern hanging wall block and mainly consist of biogenic sand, which is disposed in oblong parallel or sub-parallel ridges (Fig. 3); these sediments constitute the SW and NE sector of the submarine sand dune field referred to section 4.1. The stratigraphic resolution of the upper seabed substrate due to its coarse texture and increased occurrence of biogenic material in the sediments comprising the submarine dunes is not satisfactory. However, in some cases, the recorded subsurface reflectors exhibit an arrangement independent of seabed morphology. The sedimentary layers beneath the sand dunes display a strong reflective character (Fig. 7), which recommends their coarse composition. The accurate mapping of the location and thickness of the upper and underlying sediment layers is not feasible due to the restricted penetration of the used subbottom profiler.

The sediments of the uppermost seabed substrate of the deep hanging wall block in the southwestern part of the study area are finer, since seismic profiles demonstrate an acoustically transparent layer of a few meters in thickness (up to $10 \mathrm{~m}$ ) (Fig. 5, 6 and 7). The material comprising this acoustic layer, named as Unit A, is probably composed of mud and it has been rather formed by the accumulation of distant prodelta deposits. Below Unit A, a Unit B comprising a set of strong reflectors with distinct characteristics is identified (Fig. 5,6 and 7), which implies the existence of different sedimentation conditions (e.g., different sediment source, change in the size of available depositional area, hydrodynamic regime modification, subaerial erosion) in some locations. This clue suggests that prior to the commencement of sedimentation in the uppermost marine unit the depositional environment was different. Perissoratis and Mitropoulos (1989) argue that during the LGM (19,000-20,000 yrs BP) the study area was land and partly eroded under subaearial conditions and only a limited area situated in the southwest part was functioning as a lake. Later, during the 
post-glacial period, the sea level rose and gradually inundated the study area. The final pattern of the sedimentation processes that dominate the area nowadays was established about 6,000 yrs BP, when the rate of sea transgression slowed down and sea-level stand had approached the present one.

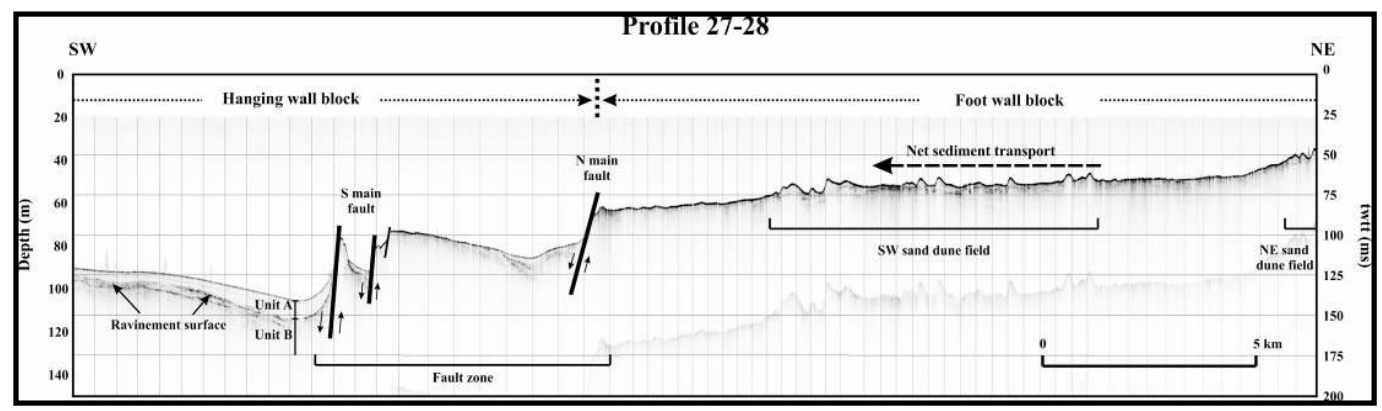

Figure 7 - Seismic-reflection profile indicating the acoustic units beneath the sand dune field and underneath the seafloor of the deep hanging wall block (extreme left side of the profile). For profile location see Figure 1.

\subsection{Bulk mineralogy and chemistry of surface seabed sediments}

The preliminary results of bulk mineralogical analysis show that surface sands (named as "Kavala sands") covering the Loutra Eleftheron-Nea Peramos inner continental shelf consist mainly of quartz ( 15-35\%), plagioclase ( 10-25\%), K-feldspar ( 5-20\%) and calcite ( 5-20\%), whereas amphibole, biotite, pyroxenes and epidote occur in smaller quantities. Ti-magnetite, rutile, titanite, ilmenite, zircon, barite, apatite, pyrite and clay minerals appear as accessory mineral phases ( $5 \%$ in total). Allanite and less often monazite and xenotime are the REE-bearing mineral phases, which are distributed throughout the surface sediments. They are found as fine-grained sand crystals, either in the form of single crystals or within granitic fragments, along with quartz and feldspars. Allanites have noticeable thorium contents (up to $3.3 \%$ ), whereas monazites include relatively high amounts of REE and thorium contents ( $\Sigma \mathrm{REE}+\mathrm{Th}=44.43-62.65 \%)$. The total amounts of $\Sigma \mathrm{REE}+\mathrm{Th}+\mathrm{Y}$ from the whole-rock chemistry analyses are in accordance with the modal composition of the REEbearing minerals and can be distinguished into four groups depending on their REE composition (Fig. 8). Based upon petrographic observations, mineral chemistry analyses, as well as whole-rock chemistry compositions, the estimated amounts of REE-bearing minerals within the "Kavala sands" range between $0.1 \mathrm{wt} . \%$ and $0.9 \mathrm{wt} . \%$.

\section{Conclusions}

The shallow continental shelf west of the Kavala Bay (Loutra Eleptheron-Nea Peramos) is characterized by (i) a fault system that shows contrasting tiered displacements and (ii) an extended field of sand dunes arranged in oblong parallel or sub-parallel ridges.

The fault system comprises a set of two primary sigmoidal gravity faults, including a northern and a southern member (recorded lengths of $12 \mathrm{~km}$ and $5 \mathrm{~km}$, respectively), with distinct expression on the seabed, and three other secondary gravity faults situated southern of the major faults, revealing synsedimentary tectonics. The maximum values of the offset, horizontal displacement and rupture plane dip of the primary faults were estimated at $>40 \mathrm{~m},>60 \mathrm{~m}$ and $10^{\circ}$, respectively, for the northern member and $25 \mathrm{~m}, 150 \mathrm{~m}$ and $12^{\circ}$, respectively, for the southern member. The observation that the sediments of the shallow footwall block of the northern major fault differ greatly from the sediments covering the deep hanging wall block of the southern major fault emphasizes the impact of local tectonics on the sedimentary evolution of the study area. 


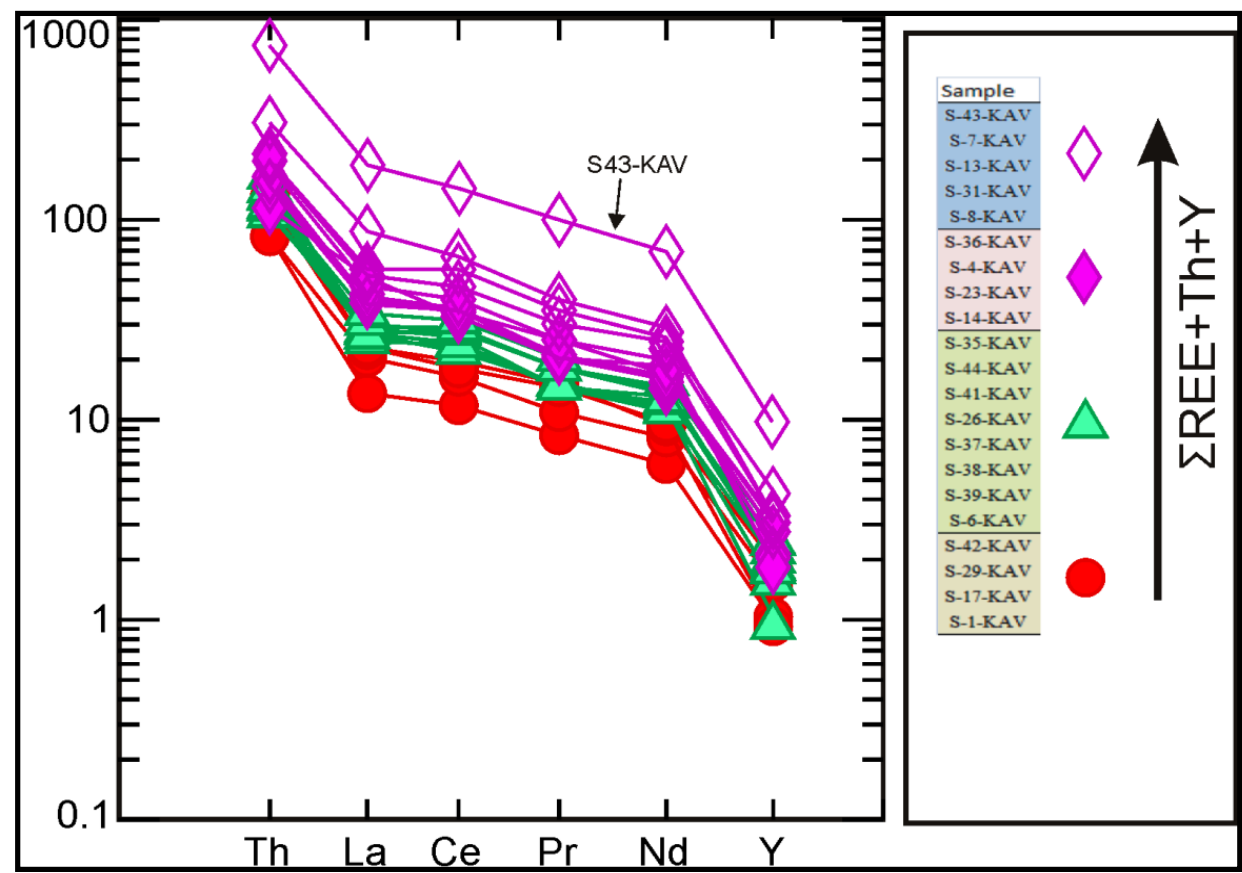

Figure 8 - Primitive mantle-normalized $\Sigma$ REE, Th and Y patterns (normalization factors from McDonough and Sun, 1995) of the "Kavala sands".

The identified sand dunes, occurring at depths from $25 \mathrm{~m}$ to $65 \mathrm{~m}$ at least and located on the footwall block of the northern major fault, usually have their longitudinal axis greater than $4 \mathrm{~km}$ and are orientated to a NW-SE direction. The large dimensions of the sand dunes (average height: 1.5-2.5 $\mathrm{m}$; maximum height: $>4 \mathrm{~m}$; maximum wave length: $>400 \mathrm{~m}$ ) as well as their orientation in relation to the coastline implies as a mechanism for their formation the intense bottom-current activity towards the NE-SW direction.

\section{Acknowledgments}

We are grateful to the crew of R/V Alkyon for their invaluable assistance during the field measurements. The research cruise was funded by the EU/NSRF YPOTHER project (351008) and realized by the Institute of Geology and Mineral Exploration (IGME) in collaboration with the Hellenic Center for Marine Research (HCMR).

\section{References}

Albarracín, S., Alcántara-Carrió, J., Montoya-Montes, I., Fontán-Bouzas, Á, Somoza, L., Amos, C.L. and Salgado, J.R., 2014. Relict sand waves in the continental shelf of the Gulf of Valencia (Western Mediterranean), Journal of Sea Research, 93, 33-46.

Brun, J.P. and Sokoutis, D., 2007. Kinematics of the Southern Rhodope Core Complex, International Journal of Earth Sciences, 96, 1079-1099.

Conispoliatis, N. and Lykousis, V., 1986. Mineralogy of the Surficial Sediments of Kavala Bay, Northern Aegean Sea, Estuarine, Coastal and Shelf Science, 23, 739-749.

Eliopoulos, D., Economou, G., Tzifas, I. and Papatrechas, C., 2014. The potential of Rare Earth Elements in Greece, Proc. of the 1st European Rare Earth Resources Conference, Milos, 47 September, 308-316. 
Jones, C.E., Tarney, J., Baker, J.H. and Gerouki, F., 1992. Tertiary granitoids of Rhodope, northern Greece: Magmatism related to extensional collapse of the Hellenic Orogen? Tectonophysics, 210, 295-314.

Kilias, A. and Mountrakis, D., 1990. Kinematics of the crystalline sequences in the western Rhodope Massif, Geologica Rhodopica, 2, 100-116.

McDonough, W.F. and Sun, S.-S., 1995. The composition of the Earth, Chemical Geology, 120, 223-253.

Neiva, A., Christofides, G., Eleftheriadis, G. and Soldatos, T., 1996. Geochemistry of granitic rocks and their minerals from the Kavala pluton, Northern Greece, Chemie der Erde, 56, 117-142.

Papadopoulos, A., Koroneos, A., Christofides, G. and Stoulos, S., 2015. Natural radioactivity distribution and gamma radiation exposure of beach sands close to Kavala pluton, Greece, Open Geosciences, 1, 407-422.

Pergamalis, F., Karageorgiou, D., Koukoulis, A. and Katsikis, I., 2001a. Mineralogical and chemical composition of near shore Nea Peramos-Loutra Eleftheron area of Kavala province, metalliferous sands, Bull. Geol. Soc. Greece, 34(3), 845-850 (in Greek).

Pergamalis, F., Karageorgiou, D.E. and Koukoulis, A., 2001b. The location of Ti, REE, Th, U, Au deposits in the seafront zone of Nea Peramos-Loutra Eleftheron area, Kavala (N. Greece) using $\gamma$ radiation, Bull. Geol. Soc. Greece, 34(3), 1023-1029 (in Greek).

Perissoratis, C. and Ioakim, Chr., 2010. Targets and results from research programs for useful primary material resources carried out by I.G.M.E. in the Greek Seas, Bull. Geol. Soc. Greece, XLIII/2, 1035-1045.

Perissoratis, C. and Mitropoulos, D., 1989. Late Quaternary Evolution of the Northern Aegean Shelf, Quaternary Research, 32, 36-50.

Perissoratis, C. and Van Andel, T.H., 1988. Late Pleistocene unconformity in the Gulf of Kavala, Northern Aegean, Greece, Marine Geology, 81, 53-61.

Perissoratis, C., Angelopoulos, I. and Mitropoulos, D., 1987. Exploring the offshore area of NE Greece for placer deposits: Geologic framework and preliminary results. In: Teleki, P.G., Dobron, M.R., Moore, J.R. and Stackelberg, U.V., eds., Marine minerals: Advances in research and resource assessment, Proc. of the NATO Advanced Research Workshop on Marine Minerals: Resource Assessment Strategies, Gregynog, 10-16 June, 1985, D. Reidel Company 588, 57-70, ISBN-10: 9027724369.

Perissoratis, C., Moorby, S.A., Angelopoulos, I., Cronan, D.S., Papavasiliou, C., Konispoliatis, N., Sakellariadou, F. and Mitropoulos, D., 1988. Mineral concentrations in the recent sediments off Eastern Macedonia, Northern Greece: Geological and Geochemical Considerations, Special Publication No 6 of the Society for Geology Applied to Mineral Deposits, 530-552.

Snedden, J.W., Tillman, R.W. and Culver, S.J., 2011. Genesis and evolution of a mid-shelf, stormbuilt sand ridge, New Jersey continental shelf, USA, Journal of Sedimentary Research, 81(78), 534-552. 